\title{
Routine Screening for Transgender and Gender Diverse Adults Taking Gender-Affirming Hormone Therapy: a Narrative Review
}

\author{
Sean J. Iwamoto, MD ${ }^{1,2,3}$ (D) Frances Grimstad, MD, MS , Michael S. Irwig, MD ${ }^{5,6}$, and \\ Micol S. Rothman, $\mathrm{MD}^{7,3}$
}

\begin{abstract}
'Division of Endocrinology, Metabolism \& Diabetes, Department of Medicine, University of Colorado, Anschutz Medical Campus, Aurora, CO, USA; ${ }^{2}$ Department of Endocrinology, Medicine Service, Rocky Mountain Regional Veterans Affairs Medical Center, VA Eastern Colorado Health Care System, Aurora, CO, USA; ${ }^{3}$ UCHealth Integrated Transgender Program, Aurora, CO, USA; ${ }^{4}$ Division of Gynecology, Department of Surgery, Boston Children's Hospital, Boston, MA, USA; ${ }^{5}$ Division of Endocrinology, Beth Israel Deaconess Medical Center, Boston, MA, USA; ${ }^{6} \mathrm{Harvard}$ Medical School, Boston, MA, USA.
\end{abstract}

Despite the growing number of adult transgender and gender diverse (TGD) patients seeking health services, there are many unknowns regarding how routine screening recommendations should be applied to TGD persons receiving gender-affirming hormone therapy (GAHT). Patients taking GAHT may have disease risks that differ from what is expected based on their sex assigned at birth or affirmed gender identity. We discuss two patient cases, one transgender man and one transgender woman who present for routine medical care, to review several conditions that may be impacted by the hormones utilized in masculinizing and feminizing GAHT and for which screening recommendations are available for TGD adults: cardiovascular risk factors, osteoporosis, breast cancer, cervical cancer, and prostate cancer. We reviewed the TGD-specific screening recommendations from several major medical organizations and programs and found them to be largely based upon expert opinion due to a lack of evidence. The goal of this narrative review is to assist healthcare professionals in counseling and screening their TGD patients when and where appropriate. Not all TGD adults have the ability or need to receive routine medical care from a specialized TGD health clinic; therefore, it is essential for all healthcare professionals involved in routine and genderaffirming care to have knowledge about these conditions and screenings.

KEY WORDS: transgender; screening; cardiovascular disease; osteoporosis; cancer.

J Gen Intern Med 36(5):1380-9

DOI: $10.1007 / \mathrm{s} 11606-021-06634-7$

(c) This is a U.S. government work and not under copyright protection in the U.S.; foreign copyright protection may apply 2021

Prior Presentations: Presented as a mini-symposium at the U.S. Professional Association for Transgender Health 2019 Meeting in Washington, DC, on September 7, 2019.

Received July 27, 2020

Accepted January 17, 2021

Published online February 5, 2021

\section{INTRODUCTION}

An estimated 1.4 million people in the USA ( $0.6 \%$ of the adult population) identify as transgender or gender diverse (TGD), meaning their gender identity does not align with their sex assigned at birth. ${ }^{1}$ Many TGD individuals report negative experiences with the healthcare system, fears of discrimination and mistreatment, and lack of insurance coverage for genderaffirming hormone therapy (GAHT) and gender-affirming surgery (GAS). ${ }^{2}$ Additionally, healthcare professionals report limited to no training in TGD health and discomfort in providing care. ${ }^{3}$

Routine care includes screenings to detect potential health problems in asymptomatic persons. Typically, screening recommendations are based on the quality of evidence available to determine the need for testing a population. Several factors must be considered including overall disease incidence and prevalence and the quality of a screening tool to accurately detect disease. Screening recommendations may be overarching for all adults or specific to the presence of tissues or organs. For TGD patients, a proper history needs to include a thorough "organ inventory" to avoid assuming the presence or absence of tissues and organs based on sex assigned at birth or gender identity.

This narrative review examines the available evidence and TGD-specific recommendations from medical societies and healthcare organizations for common screenings for several diseases that may be impacted by utilization of masculinizing (e.g., testosterone) or feminizing (e.g., estrogen with or without antiandrogen) GAHT, including conditions in which applying general population guidelines may over- or underestimate the cost-effectiveness of screening TGD persons on GAHT. ${ }^{4} \mathrm{We}$ identified each organization's self-defined level of strength and/or quality of evidence for screening recommendations for cardiovascular risk factors, osteoporosis, breast cancer; cervical cancer in transgender men; and prostate cancer in transgender women. We designated recommendations as "ungraded" if they did not specify a level of strength or quality of evidence, which reveals areas for much-needed future research. 
Herein, acknowledging limitations of ever-changing terminology and definitions, we use the terms $T G D$ (for transgender and gender diverse), transgender men (generally, assigned female at birth but currently have male gender identity; inclusive of transmasculine/nonbinary persons for the purposes of this manuscript), and transgender women (generally, assigned male at birth but currently have female gender identity; inclusive of transfeminine/nonbinary persons for the purposes of this manuscript) in describing study results and screening recommendations. Table 1 provides definitions for terms used in this paper.

Table 1 Terminology

\begin{tabular}{|c|c|}
\hline Term/phrase & Definition \\
\hline Cisgender & $\begin{array}{l}\text { Describes persons whose gender identity } \\
\text { aligns with their sex assigned at birth } \\
\text { (i.e., not transgender) }\end{array}$ \\
\hline Gender diverse & $\begin{array}{l}\text { Persons who may identify and present } \\
\text { themselves as both or alternatively male } \\
\text { and female, as neither male nor female, } \\
\text { or as a gender outside the male/female } \\
\text { binary (i.e., nonbinary). }\end{array}$ \\
\hline Gender dysphoria & $\begin{array}{l}\text { The distress and unease associated when } \\
\text { a person's gender identity and sex } \\
\text { assigned at birth do not align. The phrase } \\
\text { "gender identity disorder" is no longer } \\
\text { used, particularly after the } 2013 \\
\text { American Psychiatric Association's } \\
\text { DSM-5 replaced it with "gender dys- } \\
\text { phoria." }\end{array}$ \\
\hline Gender identity & $\begin{array}{l}\text { A person's innate, self-identified gender } \\
\text { (e.g., as a man, woman, or something } \\
\text { else) that may or may not align with that } \\
\text { person's external genitalia or sex } \\
\text { assigned at birth. Gender identity is not } \\
\text { visible to other people. }\end{array}$ \\
\hline $\begin{array}{l}\text { Gender-affirming hormone } \\
\text { therapy (GAHT) }\end{array}$ & $\begin{array}{l}\text { The use of medical therapies (e.g., } \\
\text { estrogens, anti-androgens, testosterone, } \\
\text { GnRH agonists) to reduce gender } \\
\text { dysphoria. }\end{array}$ \\
\hline $\begin{array}{l}\text { Gender-affirming surgery } \\
\text { (GAS) }\end{array}$ & $\begin{array}{l}\text { The surgical part of gender-affirming } \\
\text { management. Procedures may include } \\
\text { facial surgery, gonadectomy, hysterecto- } \\
\text { my, mastectomy, implants, penectomy, } \\
\text { vaginoplasty, phalloplasty, } \\
\text { metoidioplasty. }\end{array}$ \\
\hline Nonbinary & $\begin{array}{l}\text { Describes persons whose gender identity } \\
\text { falls outside male and female binary } \\
\text { definitions. This may include identifying } \\
\text { as both or alternating male and female, } \\
\text { neither male or female, more masculine, } \\
\text { more feminine, or something else. }\end{array}$ \\
\hline Transgender & $\begin{array}{l}\text { Describes persons whose gender identity } \\
\text { differs from their sex assigned at birth; } \\
\text { independent of the decision to use } \\
\text { GAHT or undergo GAS. This is an } \\
\text { adjective. The terms "transgendered" or } \\
\text { "transgenders" should not be used. }\end{array}$ \\
\hline $\begin{array}{l}\text { Transgender men/ } \\
\text { transmasculine }\end{array}$ & $\begin{array}{l}\text { Generally, refers to persons who were } \\
\text { assigned female at birth but have male/ } \\
\text { masculine gender identity. }\end{array}$ \\
\hline $\begin{array}{l}\text { Transgender women/ } \\
\text { transfeminine }\end{array}$ & $\begin{array}{l}\text { Generally, refers to persons who were } \\
\text { assigned male at birth but have female/ } \\
\text { feminine gender identity. }\end{array}$ \\
\hline
\end{tabular}

DSM-5, Diagnostic and Statistical Manual of Mental Disorders, Fifth Edition; GnRH, gonadotrophin-releasing hormone

\section{CASES}

\section{Case 1}

TR is a 40-year-old, non-Hispanic Black transgender man who presents to the family medicine clinic with questions regarding health maintenance. He is healthy and his only medication is testosterone cypionate $60 \mathrm{mg}$ intramuscularly weekly since age 19 years. TR underwent bilateral mastectomy at age 22 years and hysterectomy-oophorectomy at age 23 years. His vital signs are normal and physical exam is unremarkable. How do you advise TR about screening tests?

\section{Case 2}

$\mathrm{AM}$ is a 63-year-old, Hispanic white, and Asian transgender woman who presents to a new primary care clinic for an annual physical. She has been on an estradiol patch and spironolactone since age 56 years and has not undergone any GAS. AM has depression and hypertension and takes citalopram and lisinopril. There is a family history of coronary artery disease in her father and osteoporosis with hip fracture in her mother. She quit tobacco prior to initiating GAHT but smoked for 35 years prior. Vital signs were significant for a blood pressure of 141/82 $\mathrm{mmHg}$ 5 min after remaining seated; the rest of the exam was unremarkable. How do you counsel AM about screening tests?

\section{CARDIOVASCULAR RISK FACTORS AMONG TRANSGENDER AND GENDER DIVERSE ADULTS}

Cardiovascular disease is the most common cause of death in adults worldwide. ${ }^{5}$ Cardiovascular risk data are inconsistent with some, but not all, studies reporting a higher risk in transgender women compared to transgender men on GAHT ${ }^{6-8}$ Recent systematic and narrative reviews on cardiovascular disease in TGD adults reported low absolute rates of myocardial infarction (MI), venous thromboembolism (VTE), and ischemic stroke but the average age of the populations studied was relatively young. ${ }^{6,7}$ Cross-sectional epidemiological data from the 2014 to 2017 U.S. Behavioral Risk Factor Surveillance System (BRFSS) surveys revealed in a multivariate adjusted model that transgender men were 4.90 (95\% CI 2.21-10.9) and 2.53 (95\% CI 1.14-5.63) times as likely to self-report a history of MI compared to cisgender women and men, respectively, whereas transgender women were 2.56 (95\% CI 1.78-3.68) times as likely to self-report a history of MI compared to cisgender women but did not have higher odds compared to cisgender men. ${ }^{9}$

When cardiovascular events among TGD adults in retrospective cohort studies are compared to reference (presumed cisgender) populations, transgender women have higher rates of VTE and ischemic stroke compared to reference men and women as well as higher rates of MI compared to reference women but not reference men. ${ }^{10,11}$ Transgender men in those studies had similar risks of VTE and ischemic stroke compared to reference populations, though recent analysis of the Amsterdam 
transgender men cohort showed higher risk of MI compared to reference women but not reference men. ${ }^{10,11}$ Interpretation of cardiovascular risk among TGD adults needs to be considered in the context of cisgender adults' risk, absolute rates of cardiovascular events, relatively young ages at initiation of GAHT in persons that were studied, duration of GAHT, types and routes of administration of GAHT, and lack of long-term prospective data. $^{6,7,12}$

\section{Lipids, Blood Pressure, Body Weight, and Type 2 Diabetes Mellitus}

GAHT may adversely affect lipids, blood pressure, and body weight, although there are inconsistencies across studies. ${ }^{7,13,14}$ A systematic review and meta-analysis of 24 months of testosterone therapy in transgender men reported mean increases in triglycerides (21.4 mg/dL [95\% CI 0.1-42.6]) and LDL-cholesterol (17.8 mg/dL [95\% CI 3.5-32.1]) and a mean decrease in HDLcholesterol $(-8.5 \mathrm{mg} / \mathrm{dL}[95 \% \mathrm{CI}-13.0$ to -3.9$]){ }^{6}$ The same meta-analysis of GAHT for 24 months in transgender women reported a mean increase in triglycerides $(31.9 \mathrm{mg} / \mathrm{dL}$ [95\% CI 3.9-59.9]) but no changes to the other lipid parameters. ${ }^{6}$ Transdermal estrogen may mitigate the rise in triglycerides seen with oral estrogens.

A recent European Network for the Investigation of Gender Incongruence study was the largest study $(n=430)$ that assessed blood pressure before and after initiating GAHT. ${ }^{15}$ In contrast to earlier smaller studies, it found that GAHT did not significantly change systolic blood pressure (SBP) but increased diastolic blood pressure (DBP) by $3 \mathrm{mmHg}$ (95\% CI 1-2) in transgender men, and the difference did not differ by testosterone formulation. $^{12,15,16}$ In transgender women, SBP and DBP decreased significantly (3 mmHg [95\% CI 1-5] and $2 \mathrm{mmHg}$ [95\% CI 0 $3]$; respectively), with comparable decreases between oral and transdermal estrogen formulations and without correlation to serum testosterone and estradiol levels.

GAHT is also associated with weight gain in both transgender men (2.2-3.5 kg over 1-2 years) and transgender women (1-3 kg over 1-2 years). ${ }^{13,}{ }^{14}$ A meta-analysis of prospective studies calculated a mean difference of $1.7 \mathrm{~kg}(95 \%$ CI $0.7-$ 2.7) after 6 to 24 months of testosterone in transgender men, without clear differences between routes of administration, and driven by significant decreases in body fat and increases in lean mass. ${ }^{17}$ In transgender women, the mean difference in body weight was $1.8 \mathrm{~kg}$ (95\% CI 0.2-3.4) after 12 months of GAHT, associated with oral rather than transdermal estrogen, and driven by significant increases in body fat and decreases in lean mass. ${ }^{17}$ According to 2014 to 2017 BRFSS data, transgender men and women were significantly more likely to selfreport being overweight compared to cisgender women (adjusted OR 1.54 [95\% CI 1.07-2.24] and 1.34 [95\% CI 1.05$1.72]$, respectively), but not compared to cisgender men. ${ }^{8}$

While type 2 diabetes mellitus is a significant risk factor for cardiovascular disease, the role of GAHT on diabetes risk or impaired glucose metabolism is unclear. In a cross-sectional
Belgian study, type 2 diabetes mellitus prevalence was higher in transgender men on GAHT compared to age-matched control women (36.2 vs. 0/1000 persons, $P<0.001)$ but not control men $(P=0.06)$, and transgender women on GAHT had higher type 2 diabetes mellitus prevalence compared to age-matched control men and women (42.0 vs. $6.2 / 1000$ persons, $P=0.04 ; 42.0$ vs. $14.9 / 1000$ persons, $P=0.021$, respectively). ${ }^{18}$ Data from the 2014 to 2017 BRFSS revealed a higher percentage of self-reported diabetes among transgender women compared to cisgender women (13.2 vs. $10.7 \%, P=0.04)$ but not cisgender men, and transgender men had similar rates of self-reported diabetes compared to both cisgender men and women. ${ }^{9}$

\section{Screening for Cardiovascular Risk Factors}

While GAHT may negatively affect some cardiovascular risk factors, screening recommendations for cardiovascular risk factors in TGD adults (Table 2) defer to general adult population guidelines. Neither frequency nor age of onset of monitoring cardiovascular risk factors in TGD patients is specified to be different from the general population.

In case 1, TR's blood pressure and body mass index were normal. He should be asked about family history of cardiovascular disease and risk factors. In case 2, AM had hypertension, normal body mass index, and a significant family history of heart disease. Her blood pressure should be repeated, and her antihypertensive regimen should be adjusted if appropriate. AM should be congratulated and encouraged to abstain from tobacco

Table 2 Screening Recommendations for Cardiovascular Risk Factors

\begin{tabular}{|c|c|c|}
\hline Organization & Recommendations & $\begin{array}{l}\text { Level of strength } \\
\text { and/or quality of ev- } \\
\text { idence* }\end{array}$ \\
\hline $\begin{array}{l}\text { Endocrine Society } \\
(2017)^{19}\end{array}$ & $\begin{array}{l}\text { Use fasting lipid } \\
\text { profiles, diabetes } \\
\text { screening, and/or other } \\
\text { diagnostic tools; moni- } \\
\text { tor weight, blood pres- } \\
\text { sure, glucose, and lipid } \\
\text { metabolism at regular } \\
\text { intervals ("regular" is } \\
\text { not defined). }\end{array}$ & $\begin{array}{l}\text { Weak } \\
\text { recommendation with } \\
\text { low-quality evidence } \\
\text { based on observation- } \\
\text { al studies or indirect } \\
\text { evidence }\end{array}$ \\
\hline $\begin{array}{l}\text { University of } \\
\text { California, San } \\
\text { Francisco } \\
\text { Transgender Care } \\
(2016)^{20}\end{array}$ & $\begin{array}{l}\text { Depending on the age } \\
\text { at which hormones are } \\
\text { begun and total length } \\
\text { of exposure, healthcare } \\
\text { professionals may } \\
\text { choose to use the } \\
\text { (cardiovascular) risk } \\
\text { calculator for the natal } \\
\text { sex, affirmed gender, or } \\
\text { an average of the two. }\end{array}$ & $\begin{array}{l}\text { Medium-strength } \\
\text { recommendation } \\
\text { based on consensus } \\
\text { expert opinion }\end{array}$ \\
\hline $\begin{array}{l}\text { World } \\
\text { Professional } \\
\text { Association for } \\
\text { Transgender } \\
\text { Health, Standards } \\
\text { of Care, Version } 7 \\
(2011)^{4}\end{array}$ & $\begin{array}{l}\text { Measure blood pressure } \\
\text { and weight at baseline } \\
\text { and subsequent visits. }\end{array}$ & Ungraded ${ }^{* *}$ \\
\hline
\end{tabular}

*Level of strength and/or quality of evidence as defined and determined by the organization

**Ungraded, strength or quality of evidence not defined by the organization 
smoking. TR and AM should have lipid panels drawn and diabetes screening performed. Both patients' estimated 10-year atherosclerotic cardiovascular disease risk can be calculated. It is unknown whether a person's calculated risk should be based on gender identity or sex assigned at birth (regardless of GAHT status and/or duration). University of California, San Francisco, for example, proposes options of calculating risk based on sex assigned at birth or affirmed gender identity (possibly making management decisions based on the highest calculated risk) or averaging the two risks calculated for both male and female.

\section{SCREENING FOR OSTEOPOROSIS IN TRANSGENDER AND GENDER DIVERSE ADULTS}

Although osteoporosis is common in older adults, it is frequently underdiagnosed and undertreated. ${ }^{21}$ Estrogen is a key regulator of bone health, and estrogen deficiency leads to the rapid decline in bone mineral density (BMD) seen in postmenopausal cisgender women as well as the more gradual loss seen in aging cisgender men. ${ }^{19,22}$

In examining data on bone health in TGD people, exogenous estrogen clearly benefits BMD. ${ }^{23}$ However, studies have shown low BMD in transgender women (up to 18-22\% reported to have low BMD), often prior to GAHT initiation. ${ }^{24,}{ }^{25}$ Questions have been raised as to whether lower physical activity, vitamin D deficiency, and tobacco use could contribute to lower baseline BMD in transgender women. After GAHT initiation, BMD increases despite increased fat mass and decreased muscle mass. ${ }^{26} \mathrm{~A}$ meta-analysis of 13 studies including 392 transgender women reported increased spine BMD at 1 year $\left(0.04 \mathrm{~g} / \mathrm{cm}^{2}[95 \% \mathrm{CI}\right.$ $0.03-0.06])$ and 2 years $\left(0.06 \mathrm{~g} / \mathrm{cm}^{2}\right.$ [95\% CI $\left.\left.0.04-0.08\right]\right)$ after GAHT, although not hip BMD. ${ }^{27}$ Nonetheless, recent data noted an elevated fracture risk in transgender women over age 50 years (4.4\% experienced a fracture) when compared to age-matched cisgender men (2.4\% [OR 1.90 (95\% CI 1.32-2.74)]) and similar to cisgender women (4.2\% [OR $1.05(95 \%$ CI $0.75-1.49)]$ ). ${ }^{28}$

Baseline studies in transgender men indicate their BMD is similar to that of the general cisgender population. With exogenous testosterone and a modest decline in estradiol, studies, including a meta-analysis with 247 transgender men after 12 and 24 months of GAHT, have shown no significant difference in BMD when compared to their baseline BMD. ${ }^{26,27}$ Recent data did not show increased fracture risk in transgender men across the lifespan; $1.7 \%$ of the transgender men experienced a fracture compared with $3.0 \%$ of the age-matched cisgender men (OR 0.57 [95\% CI $0.35-0.94]$ ) and $2.2 \%$ of age-matched cisgender women (OR 0.79 [95\% CI 0.48-1.30]). ${ }^{28}$

A more pressing area of concern is bone health in adults who underwent pubertal blockade with gonadotropinreleasing hormone $(\mathrm{GnRH})$ agonists. GnRH agonists are well-known to decrease BMD as they block endogenous sex steroid production. ${ }^{29}$ Small studies suggest BMD declines in GnRH-treated TGD youth, and although gains are made when GAHT is started, they fail to "catch up" completely to age-

Table 3 Screening Recommendations for Osteoporosis

\begin{tabular}{lll}
\hline \hline Organization & Recommendations \\
& & \\
\hline Endocrine & Transgender & Transgender \\
Society & women: & men: \\
$(2017)^{19}$ & In individuals & Screening \\
& at low risk, & should be \\
& screening for & conducted in \\
& osteoporosis & those who \\
& should be & stop \\
& conducted at & testosterone \\
& age 60 years & screening, are \\
& or in those & not compliant \\
& who are not & with hormone \\
& compliant & therapy or \\
& with hormone & who develop \\
therapy. & risks for bone \\
& & loss.
\end{tabular}

Obtain BMD measurements when risk factors for osteoporosis exist, specifically in those who stop sex hormone therapy after gonadectomy.

University of California, San Francisco

Transgender Care $(2016)^{20}$

International Society of Clinical

Densitometry $(2019)^{30}$
Transgender people (regardless of sex assigned at birth)

- Begin bone density screening at age 65 years.

- Screening between ages 50 and 64 years should be considered for those with established risk factors for osteoporosis.

- Transgender people (regardless of sex assigned at birth) who have undergone gonadectomy and have a history of at least 5 years without hormone replacement should also be considered for bone density testing, regardless of age

- TGD individuals if they have any of the following conditions:

- History of gonadectomy or therapy that lowers endogenous gonadal steroid levels prior to initiation of hormone therapy.

- Hypogonadism with no plan to take GAHT.

- Existing ISCD indications for BMD testing, such as glucocorticoid use and hyperparathyroidism, apply. $T$ - and $Z$-score calculation in TGD individuals

- $T$-Scores should be calculated using a uniform Caucasian (nonrace adjusted) female normative database for all transgender individuals of all ethnic groups; we recommend using a $T$-score of $<-2.5$ or less for diagnosis of osteoporosis in all TGD individuals age 50 years or older, regardless of hormonal status.

- Calculate $Z$-scores using the normative database that matches the gender identity of the individual.

- If requested by the ordering healthcare professional,
Strong

recommendation with low-quality evidence-based

observational studies or indirect evidence

Weak recommendation

based on consensus expert opinion

- Transgender women: - Good quality, strong recommendation supported by the available evidence, worldwide applicability - Transgender men:

- Fair quality, recommendation supported by the evidence, worldwide applicability 
Table 3. (continued)

\begin{tabular}{lll}
\hline \hline Organization & Recommendations & $\begin{array}{l}\text { Level of strength } \\
\text { and/or quality of } \\
\text { evidence* }\end{array}$ \\
\hline
\end{tabular}

$Z$-scores may also be calculated using the normative database that matches the sex recorded at birth.

*Level of strength and/or quality of evidence as defined and determined by the organization

**Ungraded, strength or quality of evidence not defined by the organization

$T G D$, transgender and gender diverse; GAHT, gender-affirming hormone therapy; ISCD, International Society of Clinical Densitometry; $B M D$, bone mineral density

matched peers even as young adults. ${ }^{23}$ Thus, the use of GnRH agonists may have long-term repercussions for adults who underwent pubertal blockade. Currently, there are no differing recommendations for this subgroup, but healthcare professionals should ask TGD adults about puberty and consider earlier osteoporosis screening if pubertal blockade occurred.

Few osteoporosis screening recommendations exist for TGD adults (Table 3) and many questions remain as to the overall prevalence of low BMD and fracture risk in TGD adults. Changes in body composition and weight after the initiation of GAHT may influence BMD and bone quality. ${ }^{23}$ Also unknown are the long-term effects of pubertal blockade and the optimal type, timing, dosage, and route of administration of GAHT for bone outcomes. Thus, global limitations exist to providing evidencebased screening recommendations.

In case $1, T R$ has a history of hysterectomy-oophorectomy and osteoporosis screening is not indicated given his age unless he decides to stop testosterone or suffers from a fragility fracture. Although no clear guidelines exist, it is reasonable to start screening TR at age 65 years if he does not develop other risk factors for osteoporosis before then. In case 2, AM's risk factors for osteoporosis are age, race, and mother's hip fracture. Additional risks (e.g., long history of tobacco smoking, though she quit 8 years ago, and possible lower BMD compared to reference populations prior to initiating GAHT) make it reasonable to order a screening DXA at this time and discuss behaviors for optimal bone health.

\section{SCREENING FOR BREAST CANCER IN TRANSGENDER MEN}

While some transgender men undergo pubertal blockade, ${ }^{29}$ most have gone through some degree of puberty with estrogen exposure and breast development, placing them at risk for breast cancer. However, breast cancer in transgender men occurs at rates from 4.3 to 5.9 per 100,000 person-years, which are just above the cisgender male incidence of 1.2 per 100,000 person-years and much lower than the cisgender female rate of 170 per 100,000 person-years. ${ }^{31-34}$ Limitations to these studies are the younger ages of TGD populations studied and paucity of TGD adults over age 60 years.

The most common type of breast cancer in transgender men is invasive ductal carcinoma (38.9\%), ${ }^{31}$ with high rates of estrogen and progesterone receptor positivity $-85.7 \%$ and $71.4 \%$, respectively - among 14 cases. Only two cases evaluated androgen receptor positivity (both were positive), and three cases had BRCA testing performed (all negative). ${ }^{31}$ Low reported numbers of breast cancer in transgender men, after long-term treatment with testosterone, may be due to reduction of glandular tissue, involution of the lobuloalveolar structures, and prominence of fibrous connective tissue. ${ }^{35}$ Not all studies identified which, if any, transgender men had undergone chest reduction GAS in advance of cancer diagnosis; however, some did report cancer diagnosis following GAS. ${ }^{31-34}$ This is likely because the intent of masculinizing chest surgery (including bilateral subcutaneous mastectomy) is to provide masculinizing contour, not complete tissue removal. $^{36}$

Despite breast cancer incidence closer to that of cisgender men, there is no recommended reduction in breast cancer screening frequency with mammography among standard guidelines for transgender men as compared to cisgender females, even after chest GAS (Table 4). The guidelines cite lack of robust data to alter present guidance. Future research can reevaluate risk and screening guidelines as the transmasculine population ages and study the impacts of chest reduction GAS on screening modality and frequency.

Mammography compresses tissues, which may be difficult in transgender men following masculinizing chest GAS. In this situation, a radiology consultation may be helpful in discussing screening mammography pros and cons. Alternatives such as ultrasound or magnetic resonance imaging may be considered if mammography cannot be utilized; however, these alternative strategies need to be studied for costeffectiveness and outcomes compared to mammography in transgender men after bilateral mastectomy. In TR's case, he had a bilateral mastectomy 18 years ago. It is recommended that he undergo annual chest wall palpation (including suband peri-areolar regions) as breast tissue may still be present after mastectomy. Mammography limitations and whether other modalities are needed if an abnormality is palpated should also be discussed with him and shared decisionmaking should be employed.

\section{SCREENING FOR BREAST CANCER IN TRANSGENDER WOMEN}

Even though the physiologies of transgender women and postmenopausal cisgender women are not completely comparable, there have been concerns that transgender women may have elevated breast cancer risk given their potential for longterm estrogen exposure. Exposure to conjugated equine estrogens (CEEs) plus medroxyprogesterone (formulations not commonly used for feminizing GAHT) in postmenopausal 
Table 4 Screening Recommendations for Breast Cancer in Transgender Men

\begin{tabular}{|c|c|c|}
\hline Organization & Recommendations & $\begin{array}{l}\text { Level of strength } \\
\text { and/or quality of } \\
\text { evidence* }\end{array}$ \\
\hline $\begin{array}{l}\text { Endocrine Society } \\
(2017)^{19}\end{array}$ & $\begin{array}{l}\text { Screening with sub- and } \\
\text { peri-areolar annual } \\
\text { breast exams after mas- } \\
\text { tectomy; if mastectomy } \\
\text { is not performed, then } \\
\text { consider mammograms } \\
\text { as recommended by the } \\
\text { American Cancer Soci- } \\
\text { ety. }\end{array}$ & Ungraded $* *$ \\
\hline $\begin{array}{l}\text { University of } \\
\text { California, San } \\
\text { Francisco } \\
\text { Transgender Care } \\
(2016)^{20}\end{array}$ & $\begin{array}{l}\text { Engage in dialogue } \\
\text { with transgender men } \\
\text { who underwent bilateral } \\
\text { mastectomy about the } \\
\text { unknown risks } \\
\text { associated with residual } \\
\text { breast tissue, as well as } \\
\text { the possible technical } \\
\text { limitations of } \\
\text { mammography. }\end{array}$ & $\begin{array}{l}\text { Strong } \\
\text { recommendation } \\
\text { based on consensus } \\
\text { expert opinion }\end{array}$ \\
\hline $\begin{array}{l}\text { American College } \\
\text { of Gynecologists } \\
(2011)^{37}\end{array}$ & $\begin{array}{l}\text { Age-appropriate } \\
\text { screening*** for breast } \\
\text { cancer should be } \\
\text { continued unless } \\
\text { mastectomy has } \\
\text { occurred. }\end{array}$ & Ungraded** \\
\hline $\begin{array}{l}\text { American } \\
\text { Roentgen Ray } \\
\text { Society }(2014)^{38}\end{array}$ & $\begin{array}{l}\text { Transgender men who } \\
\text { underwent reduction } \\
\text { mammoplasty or no } \\
\text { chest surgery: Breast } \\
\text { examinations and } \\
\text { screening } \\
\text { mammography are } \\
\text { recommended as for } \\
\text { cisgender women. } \\
\text { Transgender men after } \\
\text { bilateral mastectomy: } \\
\text { Yearly chest wall and } \\
\text { axillary examinations. } \\
\text { Preoperative } \\
\text { transgender men: } \\
\text { Mammography only if } \\
\text { patient meets usual } \\
\text { cisgender female } \\
\text { requirements. }\end{array}$ & Ungraded $* *$ \\
\hline
\end{tabular}

*Level of strength and/or quality of evidence as defined and determined by the organization

**Ungraded, strength or quality of evidence not defined by the organization

***Age-appropriate screening is defined as every 1-2 years beginning at age 40 years (for women at average risk), starting no later than age 50 years, and continuing until at least age 75 years

cisgender women with an intact uterus was associated with significantly higher breast cancer incidence but not breast cancer mortality compared to placebo, whereas exposure to CEEs alone in postmenopausal women with prior hysterectomy was associated with significantly lower breast cancer incidence and mortality compared to placebo. ${ }^{39}$ Retrospective cohort studies with different lengths of follow-up and reference groups have demonstrated few cases of breast cancer in transgender women. ${ }^{33,40}$ The estimated incidence of breast cancer from a large Dutch cohort of transgender women (4.1 per 100,000 person-years) was lower than expected when compared to cisgender females but similar to cisgender males, as referenced above. ${ }^{32} \mathrm{~A}$ more recent analysis of the same Dutch cohort with longer follow-up found that the incidence
Table 5 Screening Recommendations for Breast Cancer in Transgender Women

\begin{tabular}{|c|c|c|}
\hline Organization & Recommendations & $\begin{array}{l}\text { Level of strength } \\
\text { and/or quality of } \\
\text { evidence* }\end{array}$ \\
\hline $\begin{array}{l}\text { Endocrine Society } \\
(2017)^{19}\end{array}$ & $\begin{array}{l}\text { If no known increased } \\
\text { breast cancer risk, } \\
\text { follow screening } \\
\text { guidelines } \\
\text { recommended for } \\
\text { cisgender women. }\end{array}$ & $\begin{array}{l}\text { Weak } \\
\text { recommendation with } \\
\text { low-quality evidence- } \\
\text { based observational } \\
\text { studies or indirect } \\
\text { evidence }\end{array}$ \\
\hline University of & Screening & Weak \\
\hline California, San & mammography every 2 & recommendation \\
\hline Francisco & years starting at age 50 & based on \\
\hline $\begin{array}{l}\text { Transgender Care } \\
(2016)^{20}\end{array}$ & $\begin{array}{l}\text { years in addition to } \\
\text { being on feminizing } \\
\text { GAHT for } 5-10 \text { years. }\end{array}$ & $\begin{array}{l}\text { observational studies } \\
\text { in TGD population }\end{array}$ \\
\hline $\begin{array}{l}\text { American College } \\
\text { of Gynecologists } \\
(2011)^{37}\end{array}$ & $\begin{array}{l}\text { Age-appropriate } \\
\text { screening** for breast } \\
\text { cancer should be } \\
\text { continued. }\end{array}$ & Ungraded $* * *$ \\
\hline $\begin{array}{l}\text { American } \\
\text { Roentgen Ray } \\
\text { Society }(2014)^{38}\end{array}$ & $\begin{array}{l}\text { Transgender women } \\
\geq 50 \text { years old with past } \\
\text { or current hormone } \\
\text { use:Annual } \\
\text { mammography if the } \\
\text { patient has additional } \\
\text { risk factors such as } \\
\text { estrogen and progestin } \\
\text { use for }>5 \text { years, body } \\
\text { mass index }>35 \mathrm{~kg} / \mathrm{m}^{2} \text {, } \\
\text { and family history; } \\
\text { clinical breast } \\
\text { examination } \\
\text { recommended only for } \\
\text { educational benefit, not } \\
\text { for formal cancer } \\
\text { screening. } \\
\text { Transgender women } \\
\text { with no hormone use: } \\
\text { Routine screening is } \\
\text { not indicated unless the } \\
\text { patient has other known } \\
\text { risk factors, e.g., } \\
\text { Klinefelter syndrome. }\end{array}$ & Ungraded $* * *$ \\
\hline
\end{tabular}

*Level of strength and/or quality of evidence as defined and determined by the organization

**Age-appropriate screening is defined as every 1-2 years beginning at age 40 years (for women at average risk), starting no later than age 50 years, and continuing until at least age 75 years

***Ungraded, strength or quality of evidence not defined by the organization

$T G D$, transgender and gender diverse; GAHT, gender-affirming hormone therapy

of breast cancer in transgender women (43 per 100,000 person-years) was 46.7-fold higher compared to that in cisgender men but about one-third the incidence compared to cisgender women. ${ }^{33}$

As there is currently no evidence that breast cancer risk among transgender women is higher than that in cisgender women, recommendations for breast cancer screening in transgender women are largely based on guidelines for cisgender women (Table 5). These guidelines were created prior to the newer Dutch data showing a higher risk of breast cancer in transgender women compared to cisgender men, and thus reaffirmed the current breast cancer screening recommendation for transgender women. 
In AM's case, a screening mammogram is reasonable now because she is over age 50 years and has taken estrogen for more than 5 years. Noted caveats to breast cancer screening in transgender women include lack of evidence guiding recommendations and how to manage screening in the presence of breast implants, which some transgender women obtain as part of GAS. Mammography is the first-line screening recommended for any person with breast implants; however, it is less sensitive in detecting breast cancer in a person with breast implants compared to someone without. ${ }^{41,42}$ Ultrasound, on the other hand, is not recommended for routine screening but rather to investigate implant complications in people with pain, lumps, or asymmetries. ${ }^{43}$ Additional prospective research is needed to better characterize predictors of breast cancer in transgender women and cost-effectiveness among screening modalities.

\section{SCREENING FOR CERVICAL CANCER IN TRANSGENDER MEN}

In general, cervical cancer and human papillomavirus (HPV) infection, the cause of $99.7 \%$ of cervical cancers, are decreasing in incidence due in part to increased screening and the HPV vaccine. ${ }^{44} \mathrm{HPV}$ is predominately transmitted sexually, with penile-vaginal sex having the highest risk of transmission (though all forms of genital contact can transmit). ${ }^{45}$ There are very few cases reported in transgender men on testosterone, which may be related to some undergoing hysterectomy. ${ }^{20,} 36$ Despite this, many transgender men have a uterus and as such require cervical cancer screening.

Table 6 Screening Recommendations for Cervical Cancer in Transgender Men

\begin{tabular}{|c|c|c|}
\hline$\overline{\text { Organization }}$ & Recommendations & $\begin{array}{l}\text { Level of strength } \\
\text { and/or quality of } \\
\text { evidence* }\end{array}$ \\
\hline $\begin{array}{l}\text { Endocrine Society } \\
(2017)^{19}\end{array}$ & $\begin{array}{l}\text { If cervical tissue is } \\
\text { present, monitoring is } \\
\text { the same as for females } \\
\text { as recommended by the } \\
\text { American College of } \\
\text { Obstetricians and } \\
\text { Gynecologists }\end{array}$ & Ungraded $* *$ \\
\hline University of & Screening should be & Strong \\
\hline California, San & done in transgender & recommendation \\
\hline Francisco & men at the same & based on consensus \\
\hline $\begin{array}{l}\text { Transgender Care } \\
(2016)^{20}\end{array}$ & $\begin{array}{l}\text { intervals as } \\
\text { recommended in } \\
\text { cisgender women. }\end{array}$ & expert opinion. \\
\hline $\begin{array}{l}\text { American College } \\
\text { of Gynecologists } \\
(2011)^{37}\end{array}$ & $\begin{array}{l}\text { Age-appropriate } \\
\text { screening*** for } \\
\text { cervical cancer should } \\
\text { be continued unless } \\
\text { removal of the cervix } \\
\text { has occurred. }\end{array}$ & Ungraded $* *$ \\
\hline
\end{tabular}

*Level of strength and/or quality of evidence as defined and determined by the organization

**Age-appropriate screening is currently defined by the American College of Gynecologists as ages 21-29 years (Pap test alone every 3 years), ages 30-65 years (Pap test and HPV test every 5 years, or Pap test alone every 3 years), and potentially stopping screening after age 65 years depending on the trends of previous Pap tests and/or HPV tests
There are unique challenges associated with cervical cancer screening in transgender men (Table 6). Testosterone causes vaginal atrophy and a decrease in cervical cellularity, which can lead to inadequate Pap tests. Longer duration of testosterone treatment is associated with higher risk of inadequate Pap tests. Cervical cancer screening approaches are rapidly evolving, and newer evidence favors high-risk HPV DNA primary screening over age 25 years (recently approved by the FDA). ${ }^{46}$ While this recommendation centers on clinician-collected swabs, studies in transgender men found high concordance between healthcare professional-performed HPV DNA vaginal swabs and patient self-swabs. Self-swabs may be employed for patients who cannot tolerate a clinicianperformed swab (e.g., folks with increased dysphoria and/or emotions related to previous trauma associated with pelvic exams) to increase cervical cancer screening rates. ${ }^{47,} 48$ For those who require repeat cervical cytology due to inadequacy, vaginal estrogen prior to the repeat Pap tests may improve the collection adequate cellularity. ${ }^{49}$ TR would not need Pap testing because he already had a hysterectomy.

\section{SCREENING FOR PROSTATE CANCER IN TRANSGENDER WOMEN}

In 2012, the U.S. Preventive Services Task Force recommended against routine screening with prostate-specific antigen (PSA) testing. $^{50,51}$ The incidence of prostate cancer is much lower in transgender women compared to that in cisgender men, and estrogen causes prostate atrophy in transgender women as seen on prostate ultrasonography and biopsy. ${ }^{52}$ A review of 11 cases of prostate cancer in transgender women reported age at diagnosis of 54-78 years; the majority had metastatic disease on presentation and had 6-41 years on GAHT (mean/median 23 years). ${ }^{53}$ Another study determined a prostate cancer incidence of 72 per 100,000 person-years (95\% CI 36-145) among transgender women, and

Table 7 Screening Recommendations for Prostate Cancer in Transgender Women

\begin{tabular}{|c|c|c|}
\hline Organization & Recommendations & $\begin{array}{l}\text { Level of strength } \\
\text { and/or quality of } \\
\text { evidence* }\end{array}$ \\
\hline $\begin{array}{l}\text { Endocrine Society } \\
(2017)^{19}\end{array}$ & $\begin{array}{l}\text { Individualized screening } \\
\text { in transgender women } \\
\text { with prostate tissue } \\
\text { present according to } \\
\text { personal risk for } \\
\text { prostate cancer, with a } \\
\text { focus on shared } \\
\text { decision-making. }\end{array}$ & $\begin{array}{l}\text { Weak } \\
\text { recommendation with } \\
\text { very low-quality evi- } \\
\text { dence-based on un- } \\
\text { systematic clinical } \\
\text { observations or very } \\
\text { indirect evidence }\end{array}$ \\
\hline $\begin{array}{l}\text { University of } \\
\text { California, San } \\
\text { Francisco } \\
\text { Transgender Care } \\
(2016)^{20}\end{array}$ & $\begin{array}{l}\text { The decision to perform } \\
\text { prostate cancer } \\
\text { screening in transgender } \\
\text { women should be made } \\
\text { based on guidelines for } \\
\text { cisgender men }\end{array}$ & Ungraded $* *$ \\
\hline
\end{tabular}

*Level of strength and/or quality of evidence as defined and determined by the organization

**Ungraded, strength or quality of evidence not defined by the organization 
the adjusted hazard ratio of 0.4 (95\% CI $0.2-0.9)$ suggested a lower rate compared to reference males. ${ }^{54}$

There is no consensus on routine prostate cancer screening with PSA among adults assigned male at birth due to the low sensitivity, low specificity of the test, and no trials showing all-cause mortality benefit. ${ }^{55}$ Additionally, no data inform whether routine PSA tests should be offered to transgender women, and a reference range has not been established (Table 7). It has been suggested that the upper limit of normal PSA, if measured, be reduced to $1.0 \mathrm{ng} / \mathrm{mL}$ in transgender women with low serum testosterone. ${ }^{20,56}$ Ongoing discussion of AM's personal risk, including asking about first-degree relatives with prostate cancer, and limitations of prostate cancer screening will promote shared decision-making.

Additionally, GAS for transgender women does not include routine prostatectomy. In the setting of vaginoplasty, the prostate is anterior to the vaginal canal so digital rectal examination, if indicated, may not be feasible. If indicated, a digital neovaginal exam may be more effective for assessing the prostate, though in one study, the prostate was felt in only $48 \%$ of transgender women with this modality. ${ }^{57}$

\section{CASE SUMMARIES}

Case 1: TR, a 40-year-old, non-Hispanic Black transgender man, who is healthy, has been on testosterone for 21 years, and underwent bilateral mastectomy and hysterectomy-oophorectomy, presents to a family medicine clinic with normal vital signs and unremarkable physical exam.

\section{General recommendations for screening*}

Cardiovascular disease risk:

- Lipids and diabetes screening

- Consider calculating a baseline 10-year atherosclerotic cardiovascular disease risk score based on affirmed gender identity, sex assigned at birth, or an average of the two

- Assess family history of cardiovascular disease

Osteoporosis:

- No screening currently unless he stops testosterone or has a fragility fracture

- If no risk factors, it is reasonable to start screening at age 65 years

Breast cancer:

- Annual chest wall palpation

- Discuss limitations of a mammogram after mastectomy and employ shared decision-making

\section{Cervical cancer:}

- Not indicated after hysterectomy

\section{Prostate cancer: N/A}

*While beyond the scope of this review, other health maintenance screenings with undetermined impacts from masculinizing GAHT should be based on risk factors for those conditions (e.g., HIV, hepatitis C, lung cancer, colon cancer, anal cancer, and others).

Case 2: AM, a 63-year-old, Hispanic white, and Asian transgender woman, who has depression and hypertension, family history of coronary artery disease and osteoporosis, is a former tobacco smoker, has been on estradiol patch and spironolactone for 7 years, and has not undergone orchiectomy, presents to a primary care clinic with elevated blood pressure and unremarkable physical exam.

General recommendations for screening*

Cardiovascular disease risk:

- Lipids and diabetes screening

- Consider calculating a baseline 10-year atherosclerotic cardiovascular disease risk score based on affirmed gender identity, sex assigned at birth, or an average of the two

\section{Osteoporosis:}

- Given risk factors, it is reasonable to order a screening DXA and discuss behaviors for optimal bone health

\section{Breast cancer:}

- Screening mammogram since she is age $50+$ years and has taken estrogen for $5+$ years

\section{Cervical cancer: N/A}

Prostate cancer:

- Discuss personal risk including family history, limitations to screening, and employ shared decision-making

*While beyond the scope of this paper, other health maintenance screenings with undetermined impacts from feminizing GAHT should be based on risk factors for those conditions (e.g., HIV, hepatitis C, lung cancer, colon cancer, anal cancer, and others).

\section{CONCLUSIONS}

With increasing visibility of TGD persons, healthcare professionals are frequently initiating and monitoring medically necessary GAHT to reduce gender dysphoria and improve quality of life in their patients. Healthcare professionals and patients may have questions regarding how masculinizing and feminizing GAHT affect various medical conditions for which there are both general adult and TGD-specific screening guidelines. Given the fact that specialized TGD clinical care is not required nor do all TGD adults need or have access to such programs, it is vital for practitioners in general internal medicine and primary care to have knowledge about these screening recommendations in TGD individuals.

Additionally, while screening discussions are an important aspect of all patients' healthcare in reducing morbidity and mortality depending on underlying risks, more data are needed 
to better understand which screenings (if any) benefit from prioritization above others in the context of broader TGD health research and policy. Many social determinants of health and the intersectionality of identities impact TGD persons' access to preventive healthcare and the effectiveness of screening guidelines and, therefore, lead to health disparities within these marginalized groups. Future studies in TGD individuals, including data that separates out subgroups within the TGD population (e.g., nonbinary persons), are needed to inform evidence-based gender-affirming screening recommendations to reduce and prevent TGD-related disparities in diseases impacted by GAHT.

ACKNOWLEDGEMENTS: SII was supported by an Advanced Fellowship in Geriatrics from the Geriatric Research, Education, and Clinical Center, Rocky Mountain Regional VA Medical Center, VA Eastern Colorado Health Care System, Office of Academic Affiliations, U.S. Department of Veterans Affairs. SII receives funding through a National Institutes of Health/University of Colorado Building Interdisciplinary Research Careers in Women's Health (BIRCWH) K12 grant (supported by NIH 5 K12 HD057022-13, PIs: Regensteiner JG and Santoro NF).

Corresponding Author: Sean J. Iwamoto, MD; Division of Endocrinology, Metabolism \& Diabetes, Department of Medicine, University of Colorado, Anschutz Medical Campus, 12801 E 17th Ave, Aurora, CO 80045, USA (e-mail: sean.iwamoto@cuanschutz.edu).

\section{Author Contribution N/A}

\section{Funding $N / A$}

\section{Declarations:}

Conflict of Interest: MSR completed a one-time consulting project for AbbVie. SJI, FG and MSI declare that they do not have a conflict of interest.

\section{REFERENCES}

1. Flores AR, Herman JL, Gates GJ, Brown TNT. How many adults identify as transgender in the United States? 2016. https:// williamsinstitute.law.ucla.edu/wp-content/uploads/How-Many-AdultsIdentify-as-Transgender-in-the-United-States.pdf. Accessed 6/17/2020.

2. James SE, Herman JL, Rankin S, Keisling M, Mottet L, Anafi M. The Report of the 2015 U.S. Transgender Survey. National Center for Transgender Equality, Washington, DC, 2016, Washington, DC. 2016. https://transequality.org/sites/default/files/docs/usts/USTS-Full-Report-Dec17.pdf. Accessed 6/17/2020.

3. Shires DA, Stroumsa D, Jaffee KD, Woodford MR. Primary Care Clinicians' Willingness to Care for Transgender Patients. Ann Fam Med. 2018;16(6):555-8. doi:https://doi.org/10.1370/afm.2298

4. Coleman E, Bockting W, Botzer M, et al. Standards of care for the health of transsexual, transgender, and gender-nonconforming people, version 7. Int J Transgenderism. 2012;13:165-232.

5. World Health Organization, Cardiovascular Diseases https://www. who.int/health-topics/cardiovascular-diseases/\#tab=tab_1. Accessed 6/17/2020

6. Maraka S, Singh Ospina N, Rodriguez-Gutierrez R, et al. Sex Steroids and Cardiovascular Outcomes in Transgender Individuals: A Systematic Review and Meta-Analysis. J Clin Endocrinol Metab. 2017;102(11):3914 23. https://doi.org/10.1210/jc.2017-01643

7. Streed CG, Jr., Harfouch O, Marvel F, Blumenthal RS, Martin SS, Mukherjee M. Cardiovascular Disease Among Transgender Adults Receiving Hormone Therapy: A Narrative Review. Ann Intern Med. 2017;167(4):256-67. https://doi.org/10.7326/m17-0577
8. Caceres BA, Jackman KB, Edmondson D, Bockting wO. Assessing gender identity differences in cardiovascular disease in US adults: an analysis of data from the 2014-2017 BRFSS. J Behav Med. 2020;43(2):329-38. doi:https://doi.org/10.1007/s10865-019-00102-8

9. Alzahrani T, Nguyen T, Ryan A, et al. Cardiovascular Disease Risk Factors and Myocardial Infarction in the Transgender Population. Circ Cardiovasc Qual Outcomes. 2019;12(4):e005597. https://doi.org/10. 1161/CIRCOUTCOMES.119.005597

10. Getahun D, Nash R, Flanders WD, et al. Cross-sex Hormones and Acute Cardiovascular Events in Transgender Persons: A Cohort Study. Ann Intern Med. 2018;169(4):205-13. https://doi.org/10.7326/M17-2785

11. Nota NM, Wiepjes CM, de Blok CJM, Gooren LJG, Kreukels BPC, den Heijer M. Occurrence of Acute Cardiovascular Events in Transgender Individuals Receiving Hormone Therapy. Circulation. 2019;139(11):14612. https://doi.org/10.1161/CIRCULATIONAHA.118.038584

12. Irwig MS. Cardiovascular health in transgender people. Rev Endocr Metab Disord. 2018;19(3):243-51. https://doi.org/10.1007/s11154018-9454-3

13. Irwig MS. Testosterone therapy for transgender men. Lancet Diabetes Endocrinol. 2017;5(4):301-11. https://doi.org/10.1016/S2213-8587(16) 00036-X

14. Tangpricha V, den Heijer M. Oestrogen and anti-androgen therapy for transgender women. Lancet Diabetes Endocrinol. 2017;5(4):291-300. https://doi.org/10.1016/S2213-8587(16)30319-9

15. van Velzen DM, Paldino A, Klaver M, et al. Cardiometabolic Effects of Testosterone in Transmen and Estrogen Plus Cyproterone Acetate in Transwomen. J Clin Endocrinol Metab. 2019;104(6):1937-47. https:// doi.org/10.1210/jc.2018-02138

16. Elamin MB, Garcia MZ, Murad MH, Erwin PJ, Montori VM. Effect of sex steroid use on cardiovascular risk in transsexual individuals: a systematic review and meta-analyses. Clin Endocrinol (Oxf). 2010;72(1):1-10. https://doi.org/10.1111/j.1365-2265.2009.03632.x

17. Klaver M, Dekker M, de Mutsert R, Twisk JWR, den Heijer M. Crosssex hormone therapy in transgender persons affects total body weight, body fat and lean body mass: a meta-analysis. Andrologia. 2017;49(5). https://doi.org/10.1111/and. 12660

18. Wierckx K, Elaut E, Declercq E, et al. Prevalence of cardiovascular disease and cancer during cross-sex hormone therapy in a large cohort of trans persons: a case-control study. Eur J Endocrinol. 2013;169(4):4718. https://doi.org/10.1530/eje-13-0493

19. Hembree WC, Cohen-Kettenis PT, Gooren L, et al. Endocrine Treatment of Gender-Dysphoric/Gender-Incongruent Persons: An Endocrine Society Clinical Practice Guideline. J Clin Endocrinol Metab. 2017;102(11):3869-903. https://doi.org/10.1210/jc.2017-01658

20. UCSF Transgender Care, Department of Family and Community Medicine, University of California San Francisco, Guidelines for the Primary and Gender-Affiring Care of Transgender and Gender Nonbinary People; 2nd edition. Deutsch MB, ed. June 2016. https://transcare.ucsf.edu/ guidelines. Accessed 6/17/2020.

21. Lewiecki EM, Ortendahl JD, Vanderpuye-Orgle J, et al. Healthcare Policy Changes in Osteoporosis Can Improve Outcomes and Reduce Costs in the United States. JBMR Plus. 2019;3(9):e10192. https://doi. org/10.1002/jbm4.10192

22. Cauley JA. Estrogen and bone health in men and women. Steroids. 2015;99(Pt A):11-5. https://doi.org/10.1016/j.steroids.2014.12. 010

23. Rothman MS, Iwamoto SJ. Bone Health in the Transgender Population. Clin Rev Bone Miner Metab. 2019;17(2):77-85. https://doi.org/10.1007/ s12018-019-09261-3

24. Van Caenegem E, Taes $\mathbf{Y}$, Wierckx $\mathbf{K}$, et al. Low bone mass is prevalent in male-to-female transsexual persons before the start of cross-sex hormonal therapy and gonadectomy. Bone. 2013;54(1):92-7. https:// doi.org/10.1016/j.bone.2013.01.039

25. Fighera TM, da Silva E, Lindenau JD, Spritzer PM. Impact of cross-sex hormone therapy on bone mineral density and body composition in transwomen. Clin Endocrinol (Oxf). 2018;88(6):856-62. https://doi.org/ 10.1111/cen.13607

26. Wiepjes CM, de Jongh RT, de Blok CJ, et al. Bone Safety During the First Ten Years of Gender-Affirming Hormonal Treatment in Transwomen and Transmen. J Bone Miner Res. 2019;34(3):447-54. https://doi.org/ 10.1002/jbmr.3612

27. Singh-Ospina N, Maraka S, Rodriguez-Gutierrez R, et al. Effect of Sex Steroids on the Bone Health of Transgender Individuals: A Systematic Review and Meta-Analysis. J Clin Endocrinol Metab. 2017;102(11):390413. https://doi.org/10.1210/jc.2017-01642 
28. Wiepjes CM, de Blok CJ, Staphorsius AS, et al. Fracture Risk in Trans Women and Trans Men Using Long-Term Gender-Affirming Hormonal Treatment: A Nationwide Cohort Study. J Bone Miner Res. 2020;35(1):64-70. https://doi.org/10.1002/jbmr.3862

29. Panagiotakopoulos L. Transgender medicine - puberty suppression. Rev Endocr Metab Disord. 2018;19(3):221-5. https://doi.org/10.1007/ s11154-018-9457-0

30. Rosen HN, Hamnvik OR, Jaisamrarn U, et al. Bone Densitometry in Transgender and Gender Non-Conforming (TGNC) Individuals: 2019 ISCD Official Position. J Clin Densitom. 2019;22(4):544-53. https://doi. org/10.1016/j.jocd.2019.07.004

31. Joint R, Chen ZE, Cameron S. Breast and reproductive cancers in the transgender population: a systematic review. BJOG. 2018;125(12):150512. https://doi.org/10.1111/1471-0528.15258

32. Gooren LJ, van Trotsenburg MA, Giltay EJ, van Diest PJ. Breast cancer development in transsexual subjects receiving cross-sex hormone treatment. J Sex Med. 2013;10(12):3129-34. https://doi.org/10.1111/ jsm. 12319

33. de Blok CJM, Wiepjes CM, Nota NM, et al. Breast cancer risk in transgender people receiving hormone treatment: nationwide cohort study in the Netherlands. BMJ. 2019;365:11652. https://doi.org/10. 1136/bmj.11652

34. Brown GR, Jones KT. Incidence of breast cancer in a cohort of 5,135 transgender veterans. Breast Cancer Res Treat. 2015;149(1):191-8. https://doi.org/10.1007/s10549-014-3213-2

35. Slagter MH, Gooren LJ, Scorilas A, Petraki CD, Diamandis EP. Effects of long-term androgen administration on breast tissue of female-to-male transsexuals. J Histochem Cytochem. 2006;54(8):905-10. https://doi. org/10.1369/jhc.6A6928.2006

36. Monstrey SJ, Ceulemans P, Hoebeke P. Sex Reassignment Surgery in the Female-to-Male Transsexual. Semin Plast Surg. 2011;25(3):229-44. https://doi.org/10.1055/s-0031-1281493

37. Committee on Health Care for Underserved W. Committee Opinion no. 512: health care for transgender individuals. Obstet Gynecol 2011;118(6):1454-8. https://doi.org/10.1097/AOG.0b013e31823edlc1

38. Phillips J, Fein-Zachary VJ, Mehta TS, Littlehale N, Venkataraman S Slanetz PJ. Breast imaging in the transgender patient. AJR Am J Roentgenol. 2014;202(5):1149-56. https://doi.org/10.2214/AJR. 13. 10810

39. Chlebowski RT, Anderson GL, Aragaki AK, et al. Association of Menopausal Hormone Therapy With Breast Cancer Incidence and Mortality During Long-term Follow-up of the Women's Health Initiative Randomized Clinical Trials. JAMA. 2020;324(4):369-80. https://doi.org/ 10.1001/jama.2020.9482

40. Eismann J, Heng YJ, Fleischmann-Rose $\mathbf{K}$, et al. Interdisciplinary Management of Transgender Individuals at Risk for Breast Cancer: Case Reports and Review of the Literature. Clin Breast Cancer. 2018. https:// doi.org/10.1016/j.clbc.2018.11.007

41. Pivo S, Montes J, Schwartz S, et al. Breast Cancer Risk Assessment and Screening in Transgender Patients. Clin Breast Cancer. 2017;17(5):e225-e7. https://doi.org/10.1016/j.clbc.2016.08.003

42. Miglioretti DL, Rutter CM, Geller BM, et al. Effect of breast augmentation on the accuracy of mammography and cancer characteristics. JAMA. 2004;291(4):442-50. https://doi.org/10.1001/jama.291.4.442

43. Evans A, Trimboli RM, Athanasiou A, et al. Breast ultrasound: recommendations for information to women and referring physicians by the European Society of Breast Imaging. Insights Imaging. 2018;9(4):449-61. https://doi.org/10.1007/s13244-018-0636-Z

44. Committee on Practice B-G. Practice Bulletin No. 168: Cervical Cancer Screening and Prevention. Obstet Gynecol. 2016;128(4):e111-30. https://doi.org/10.1097/AOG.0000000000001708

45. Walboomers JM, Jacobs MV, Manos MM, et al. Human papillomavirus is a necessary cause of invasive cervical cancer worldwide. J Pathol. 1999;189(1): 12-9. https://doi.org/10.1002/(SICI) 1096-9896(199909) 189: 1<12::AID-PATH431>3.0.CO;2-F

46. Huh WK, Ault KA, Chelmow D, et al. Use of primary high-risk human papillomavirus testing for cervical cancer screening: interim clinical guidance. Gynecol Oncol. 2015;136(2):178-82. https://doi.org/10. 1016/j.ygyno.2014.12.022

47. Reisner SL, Deutsch MB, Peitzmeier SM, et al. Test performance and acceptability of self- versus provider-collected swabs for high-risk HPV DNA testing in female-to-male trans masculine patients. PLoS One. 2018;13(3):e0190172. https://doi.org/10.1371/journal.pone.0190172

48. Potter J, Peitzmeier SM, Bernstein I, et al. Cervical Cancer Screening for Patients on the Female-to-Male Spectrum: a Narrative Review and Guide for Clinicians. J Gen Intern Med. 2015;30(12):1857-64. https:// doi.org/10.1007/s11606-015-3462-8

49. Adkins BD, Barlow AB, Jack A, et al. Characteristic findings of cervical Papanicolaou tests from transgender patients on androgen therapy: Challenges in detecting dysplasia. Cytopathology. 2018;29(3):281-7. https://doi.org/10.1111/cyt.12525

50. Surveillance, Epidemiology, and End Results Program (SEER), Cancer Stat Facts: Prostate Cancer. National Cancer Institute. Bethesda, MD. https://seer.cancer.gov/statfacts/html/prost.html. .

51. Kensler KH, Pernar CH, Mahal BA, et al. Racial/ethnic variation in PSA testing and prostate cancer incidence following the 2012 U.S.P.S.T.F. recommendation. J Natl Cancer Inst. 2020. https://doi.org/10.1093/ jnci/djaal71

52. van Kesteren $\mathbf{P}$, Meinhardt $\mathbf{W}$, van der Valk $\mathbf{P}$, Geldof $\mathbf{A}$, Megens $\mathbf{J}$, Gooren L. Effects of estrogens only on the prostates of aging men. J Urol. 1996;156(4):1349-53.

53. Ingham MD, Lee RJ, MacDermed D, Olumi AF. Prostate cancer in transgender women. Urol Oncol. 2018. https://doi.org/10.1016/j. urolonc.2018.09.011

54. Silverberg MJ, Nash R, Becerra-Culqui TA, et al. Cohort study of cancer risk among insured transgender people. Ann Epidemiol. 2017;27(8):499-501. https://doi.org/10.1016/j.annepidem.2017.07. 007

55. Mulhem E, Fulbright N, Duncan N. Prostate Cancer Screening. Am Fam Physician. 2015;92(8):683-8.

56. Trum HW, Hoebeke P, Gooren LJ. Sex reassignment of transsexual people from a gynecologist's and urologist's perspective. Acta Obstet Gynecol Scand. 2015;94(6):563-7. https://doi.org/10.1111/aogs.12618

57. Weyers S, De Sutter P, Hoebeke S, et al. Gynaecological aspects of the treatment and follow-up of transsexual men and women. Facts Views Vis Obgyn. 2010;2(1):35-54

Publisher's Note: Springer Nature remains neutral with regard to jurisdictional claims in published maps and institutional affiliations. 